\title{
Thymocytes selected for resistance to hydrogen peroxide show altered antioxidant enzyme profiles and resistance to dexamethasone-induced apoptosis
}

\author{
ME Tome ${ }^{1}$ and MM Briehi ${ }^{*, 1}$ \\ ${ }^{1}$ Department of Pathology, University of Arizona, Tucson, Arizona 85724, USA \\ * Corresponding author: MM Briehl, Department of Pathology, P.0. Box \\ 254043, University of Arizona, Tucson, Arizona 85724, USA \\ Tel: (520) 626-6827; Fax: (520) 626-1027; E-mail: mmbrieh|@u.arizona.edu
}

Received 26.5.00; revised 13.3.01; accepted 24.4.01

Edited by A Rosen

\begin{abstract}
Treatment of WEHI7.2 cells, a mouse thymoma-derived cell line, with dexamethasone, a synthetic glucocorticoid, causes the cells to undergo apoptosis. Previous work has shown that treatment of WEHI7.2 cells with dexamethasone results in a downregulation of antioxidant defense enzymes, suggesting that increased oxidative stress may play a role in glucocorticoid-induced apoptosis. To test whether resistance to oxidative stress causes resistance to dexamethasoneinduced apoptosis, WEHI7.2 cell variants selected for resistance to 50,100 and $200 \mu \mathrm{M} \mathrm{H}_{2} \mathrm{O}_{2}$ were developed. Resistance to $\mathrm{H}_{2} \mathrm{O}_{2}$ is accompanied by increased antioxidant enzyme activity, resistance to other oxidants and a delayed loss of viable cells after dexamethasone treatment. In the $200 \mu \mathrm{M} \mathrm{H}_{2} \mathrm{O}_{2}$-resistant cell variant the delay in cell loss is correlated with delayed release of cytochrome $c$ from the mitochondria into the cytosol. This suggests that reactive oxygen species play a role in a signaling event during steroidmediated apoptosis in lymphocytes. Cell Death and Differentiation (2001) 8, 953-961.
\end{abstract}

Keywords: thymocytes; dexamethasone; hydrogen peroxide resistance; apoptosis; glucocorticoids; steroids

Abbreviations: $\mathrm{H}_{2} \mathrm{O}_{2} \mathrm{R}$ cells, hydrogen peroxide-resistant WEHI7.2 cells; 50R, $50 \mu \mathrm{M}$ hydrogen peroxide-resistant WEHI7.2 cells; $100 \mathrm{R}, 100 \mu \mathrm{M}$ hydrogen peroxide-resistant WEHI7.2 cells; 200R, $200 \mu \mathrm{M}$ hydrogen peroxide-resistant WEHI7.2 cells; GAPDH, glyceraldehyde 3-phosphate dehydrogenase; PBS, phosphate-buffered saline; ROS, reactive oxygen species; DMSO, dimethyl sulfoxide

\section{Introduction}

Glucocorticoid-mediated apoptosis plays an important role in lymphoid tissues during maturation of thymocytes and chemotherapy in lymphoid neoplasms (reviewed in ${ }^{1}$ ). Although glucocorticoid-induced apoptosis in lymphoid tissues is well documented, the molecular events which cause the cellular commitment to apoptosis after glucocorticoid treatment are not understood.

The biological effects of glucocorticoids are mediated, for the most part, through binding of the ligand to the receptor in the cytosol and translocation of the complex to the nucleus where this complex exerts its effects on transcription. $^{2}$ Several groups have found induction or repression of a small, but growing, number of transcripts during glucocorticoid-induced apoptosis in lymphoid tissues. ${ }^{1,3-6}$ In WEHI7.2 cells, a mouse thymoma cell line, treatment with the synthetic glucocorticoid, dexamethasone, causes a number of antioxidant defense enzymes to be downregulated at the transcriptional level. ${ }^{7}$ Catalase and glutathione peroxidase, which metabolize $\mathrm{H}_{2} \mathrm{O}_{2}$; superoxide dismutase, which detoxifies $\mathrm{O}_{2}{ }^{-}$; and thioredoxin, a protein which participates in producing reducing equivalents in the cell, are all downregulated at the mRNA level shortly after dexamethasone treatment. ${ }^{7,8}$ Concomitant with the downregulation of the antioxidant defense enzymes is an increase in transcripts for glutathione S-transferase, ${ }^{7}$ an enzyme thought to be involved in detoxification of lipid peroxidation products. ${ }^{9}$ This suggests that oxidative stress may play a role in dexamethasone-induced thymocyte apoptosis.

Oxidative stress occurs when production or exposure to reactive oxygen species (ROS) outstrips the ability of the cell to remove them. This can occur by an increase in ROS production or a decrease in the ability of the cell to metabolize them. ${ }^{10}$ Results from other studies are consistent with a critical role for ROS in dexamethasoneinduced lymphocytes apoptosis: (1) exogenous treatment of thymocytes with chemical antioxidants or antioxidant enzymes protects against dexamethasone-induced apopto$\mathrm{sis}^{8,11-16}$ (2) treatment with metal chelators has been shown to inhibit this type of cell death; $;^{11,17}$ (3) culture of thymocytes under hypoxic conditions generally affords protection from dexamethasone; ${ }^{8,15,18}$ and (4) lipid peroxidation, as a measure of oxidative damage, is seen after glucocorticoid treatment in thymocytes ${ }^{19}$ and $S 49.1$ lymphocytes. ${ }^{20}$

Whether ROS are important as signals in apoptosis or produced only during the execution phase is far from clear (see discussion $\mathrm{in}^{21-23}$ ). Hyperproduction of ROS in the later (or execution) stages of apoptosis is thought to be caused by the disruption of the mitochondrial respiratory chain after release of cytochrome $c$ into the cytosol. ${ }^{14,24,25}$ ROS may also play a role in the early (or signaling) phase of apoptosis, prior to the commitment of the cell to die, when apoptosis is induced either by agents that produce ROS (e.g., $\gamma$ irradiation, paraquat) or ROS themselves ${ }^{15,17,20,26-29}$ among others. Data from several 
laboratories suggest that ROS are produced sufficiently early after dexamethasone treatment to act as mediators of steroid-induced apoptosis in lymphocytes. ${ }^{14,16,19}$

If ROS are critical to the mechanism of steroid-induced apoptosis, then bolstering the endogenous cellular antioxidant defense should protect the cells from death in the presence of steroids. By continuous growth of WEHI7.2 cells in the presence of hydrogen peroxide, we have developed several cell variants with altered antioxidant enzyme profiles. These cell variants have provided useful tools to test the importance of endogenous antioxidant defenses in dexamethasone-induced apoptosis and gain insight into the role of ROS in this process.

\section{Results}

\section{Cell growth and hydrogen peroxide resistance}

Selection for growth in the presence of hydrogen peroxide has resulted in cell populations which exhibit hydrogen peroxide resistance proportional to the selection concentration as shown in Figure 1. The $\mathrm{EC}_{50}$ for $\mathrm{H}_{2} \mathrm{O}_{2}$ in the WEHI7.2 cells was $88 \pm 4 \mu \mathrm{M} \mathrm{H}_{2} \mathrm{O}_{2}$. Selection for growth in $50 \mu \mathrm{M} \mathrm{H}_{2} \mathrm{O}_{2}$ resulted in cells with increased resistance to hydrogen peroxide $\left(\mathrm{EC}_{50}=148 \pm 5 \mu \mathrm{M} \mathrm{H}_{2} \mathrm{O}_{2}\right)$. Continuous growth in 100 or $200 \mu \mathrm{M} \mathrm{H}_{2} \mathrm{O}_{2}$ selected cells with an even greater $\mathrm{H}_{2} \mathrm{O}_{2}$ resistance as shown by an $\mathrm{EC}_{50}$ of $245 \pm 10$ or $427 \pm 5 \mu \mathrm{M}$ $\mathrm{H}_{2} \mathrm{O}_{2}$, respectively. We were unable to select for cells that could be maintained in $400 \mu \mathrm{M} \mathrm{H}_{2} \mathrm{O}_{2}$.

To determine whether selection for growth in the presence of $\mathrm{H}_{2} \mathrm{O}_{2}$ affected the rate of cell growth we compared the doubling time of the hydrogen peroxideresistant cell variants $\left(\mathrm{H}_{2} \mathrm{O}_{2} \mathrm{R}\right)$ to that of the parental WEHI7.2 cells (Table 1 ). In the absence of $\mathrm{H}_{2} \mathrm{O}_{2}$, cells resistant to $50 \mu \mathrm{M}(50 \mathrm{R}), 100 \mu \mathrm{M}(100 \mathrm{R})$ and $200 \mu \mathrm{M}$

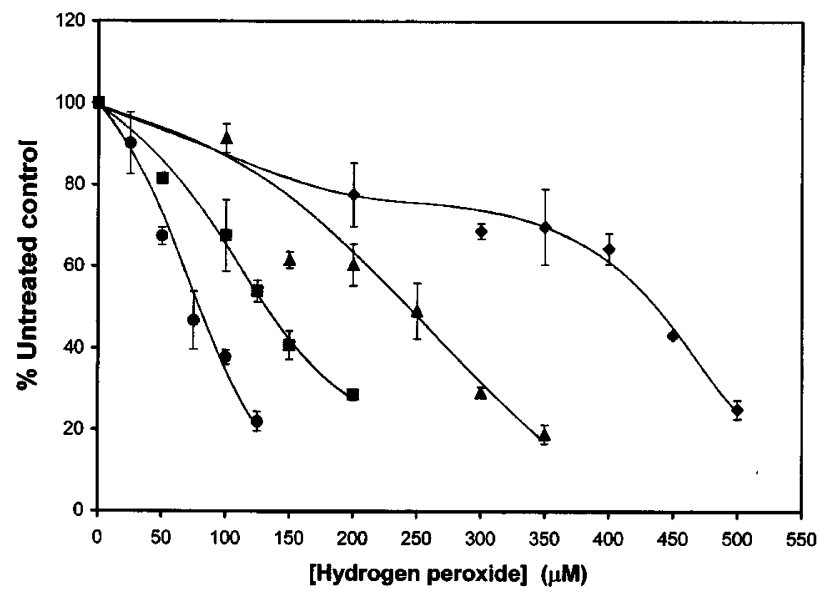

Figure 1 Growth of the $\mathrm{H}_{2} \mathrm{O}_{2}$-resistant cell variants and the WEHI7.2 parental cells in the presence of different concentrations of $\mathrm{H}_{2} \mathrm{O}_{2}$. Relative viable cell number after $48 \mathrm{~h}$ growth in the indicated $\mathrm{H}_{2} \mathrm{O}_{2}$ concentrations for the parental $(\boldsymbol{O}), 50 \mathrm{R}(\boldsymbol{\square}), 100 \mathrm{R}(\boldsymbol{\Delta})$, and 200R ( $)$ cells was measured as described in Materials and Methods. Each point is an average + S.E.M. of triplicate samples in a representative experiment, which has been replicated
Table 1 Growth of parental WEHI7.2 cells and the hydrogen peroxide-resistant cell variants

\begin{tabular}{lc}
\hline Cell variant & Doubling time (h) \\
\hline WEHI7.2 & $13.78 \pm 0.38^{*}$ \\
$50 \mathrm{R}$ & $14.62 \pm 0.76$ \\
$100 \mathrm{R}$ & $14.20 \pm 0.49$ \\
$200 \mathrm{R}$ & $14.63 \pm 0.31$ \\
\hline
\end{tabular}

*Values represent the mean \pm S.E.M. $(n=8$ or 9$)$

(200R) $\mathrm{H}_{2} \mathrm{O}_{2}$ showed slightly longer doubling times than the parental cells; however, the differences were not significant. A comparison of the doubling times in the resistant cell variants indicated no significant differences among the cell variants and no correlation between degree of hydrogen peroxide resistance and doubling time.

\section{Antioxidant enzyme profile}

Selection for growth in the presence of a drug is often accompanied by alterations in the metabolic pathways for detoxifying the compound. A comparison of antioxidant defense enzyme activities in the $\mathrm{H}_{2} \mathrm{O}_{2} \mathrm{R}$ cells showed that selection resulted in cell variants with altered antioxidant enzyme profiles (Figure 2).

Intracellular $\mathrm{H}_{2} \mathrm{O}_{2}$ can be removed by several different enzymes including catalase, glutathione peroxidase and thioredoxin peroxidase. Catalase specific activity was increased in the $50 \mathrm{R}$ cells and to an even greater extent in the cells resistant to $200 \mu \mathrm{M} \mathrm{H}_{2} \mathrm{O}_{2}$ when compared to that in the WEHI7.2 cells. The 200R cells still showed similarly elevated catalase activity after 4 months culture in the absence of $\mathrm{H}_{2} \mathrm{O}_{2}$ selection (data not shown). Surprisingly, catalase activity in the 100R cells appeared to be similar or slightly less than that of the parental cells. Two isoforms of glutathione peroxidase that detoxify cytosolic $\mathrm{H}_{2} \mathrm{O}_{2}$ have been reported, one that is seleniumdependent and another that is selenium-independent. ${ }^{30}$ Activity for each of the two glutathione peroxidase isoforms was undetectable in the parental cells under normal cell culture conditions (low selenium). Similarly, under these conditions, glutathione peroxidase activity was undetectable in the $\mathrm{H}_{2} \mathrm{O}_{2} \mathrm{R}$ cells. Supplementation of the medium with $100 \mathrm{nM} \mathrm{NaSeO}_{3}$ was required to result in measurable activity ( $82 \mathrm{mU} / \mathrm{mg}$ protein in the parental cells), suggesting glutathione peroxidase was not a major player in this system. Thioredoxin peroxidases detoxify $\mathrm{H}_{2} \mathrm{O}_{2}$ at the expense of reducing equivalents from thioredoxin and ultimately $\mathrm{NADPH} .{ }^{31}$ We have examined expression of three of the known mammalian thioredoxin peroxidase isoforms, AOE372, ${ }^{32}$ NKEFA and NKEFB. ${ }^{33}$ No alterations in constitutive mRNA levels were seen when thioredoxin peroxidase expression was normalized to GAPDH (data not shown).

Increases in antioxidant enzymes not directly involved in the detoxification of $\mathrm{H}_{2} \mathrm{O}_{2}$ were also seen (Figure 2). Total superoxide dismutase activity was slightly increased in the $50 R$ and $100 R$ cells and significantly elevated in the 200R cells when compared to the WEHI7.2 parental cells. 

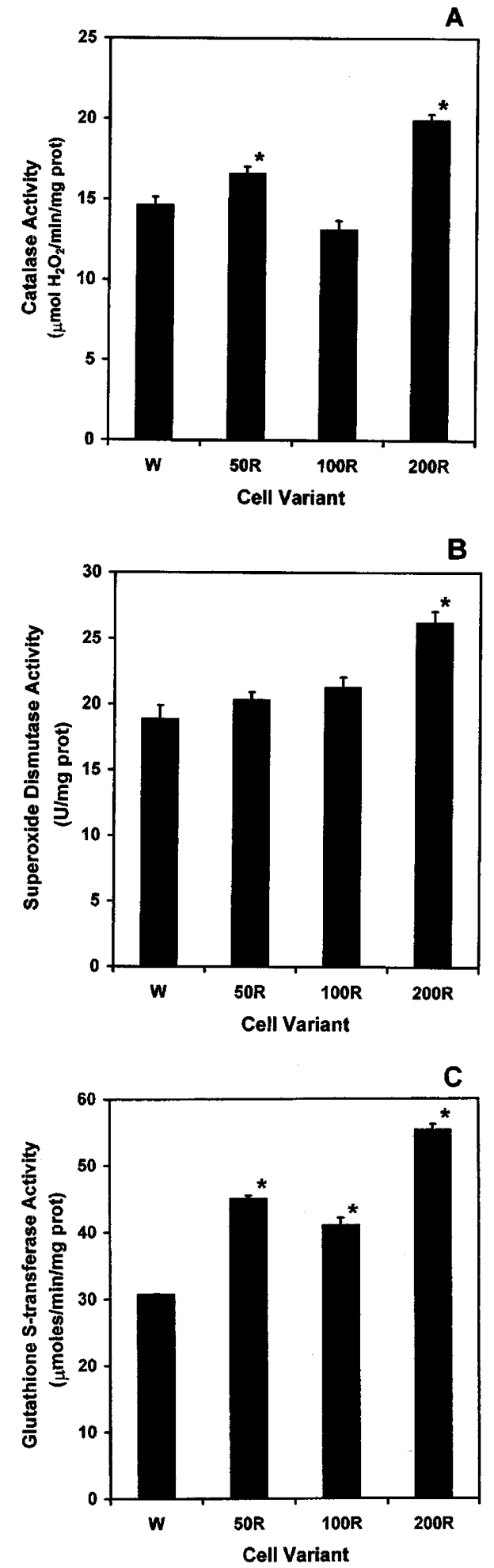

Figure 2 Antioxidant enzyme profiles in the $\mathrm{H}_{2} \mathrm{O}_{2}$-resistant cell variants and the WEHI7.2 parental cells. Catalase (A), superoxide dismutase (B) and glutathione S-transferase (C) activities, normalized to cellular protein, are shown. Enzyme activities in the parental cells are labeled W. Each bar represents the mean of triplicate samples+S.E.M. for a representative experiment which has been replicated. *Indicates significantly different from parental $(\mathrm{W})$ values
Glutathione S-transferase activity was also increased in the three $\mathrm{H}_{2} \mathrm{O}_{2} \mathrm{R}$ cell variants.

\section{Resistance to other agents}

The elevated superoxide dismutase activity in the $\mathrm{H}_{2} \mathrm{O}_{2} \mathrm{R}$ cells suggested that these cell variants might be resistant to $\mathrm{O}_{2}{ }^{--}$. To test this, the relative number of viable cells in parental and $\mathrm{H}_{2} \mathrm{O}_{2} \mathrm{R}$ cell cultures was compared following incubation in the presence of paraquat (methyl viologen). Paraquat readily enters mammalian cells and is metabolized to produce endogenous superoxide anions. ${ }^{28}$ All three hydrogen peroxide-resistant cell variants were significantly more resistant to paraquat when compared to the parental cells, but not significantly different from each other. The $\mathrm{EC}_{50}$ for paraquat in the parental cells was $46 \pm 9 \mu \mathrm{M}$ and increased to $85 \pm 19$, $90 \pm 20$ and $83 \pm 18 \mu \mathrm{M}$ in the 50R, 100R and 200R cell variants, respectively.

To determine whether the $\mathrm{H}_{2} \mathrm{O}_{2} \mathrm{R}$ cells were more resistant to other agents that are less or not dependent on ROS we compared the relative cell death in response to several agents which are known inducers of apoptosis in WEHI7.2 cells $^{34}$ and work by different mechanisms (Table 2). Treatment with etoposide, a topoisomerase II inhibitor, ${ }^{35}$ which does not cause an increase in ROS in thymocytes ${ }^{19}$ caused similar amounts of cell death in all three $\mathrm{H}_{2} \mathrm{O}_{2} \mathrm{R}$ variants and the parental cells. However, the 200R cells showed less cell death in response to treatment with thapsigargin, an endoplasmic reticulum $\mathrm{Ca}^{2+}$-ATPase pump inhibitor, ${ }^{36}$ which does cause an ROS increase in thymocytes. ${ }^{19}$ The 200R cells also showed less cell death than 50R, 100R or WEHI7.2 cells after treatment with staurosporine, a general kinase inhibitor. ${ }^{37}$ Spontaneous cell death in the 200R cell cultures was also significantly decreased when compared to parental cell cultures; however, this does not account for the observed resistance to staurosporine and thapsigargin.

\section{Protection from dexamethasone-induced apoptosis}

We next tested whether selection for hydrogen peroxide resistance resulted in cell variants that are protected from dexamethasone-induced apoptosis. After a $48 \mathrm{~h}$ treatment with dexamethasone all three $\mathrm{H}_{2} \mathrm{O}_{2}$-resistant variant cell cultures contained significantly more viable cells than the parental cell culture (Figure 3). This indicated that selection for hydrogen peroxide resistance protected against dexamethasone-induced apoptosis; however, the pattern of cell loss differed among the $\mathrm{H}_{2} \mathrm{O}_{2} \mathrm{R}$ variants. Loss of viable cells in the presence of dexamethasone appeared to be slower in the $50 \mathrm{R}$ variant than the parental cells and slowest of all in the $200 \mathrm{R}$ cells. In the $100 \mathrm{R}$ cells, the major difference was the greater increase in cell number after dexamethasone treatment compared to the parental cells. Morphological assessment of cells at selected timepoints verified that cell loss was due to apoptosis (data not shown). Functional glucocorticoid receptor number was similar in parental and $\mathrm{H}_{2} \mathrm{O}_{2} \mathrm{R}$ cells, as was the growth of the cells in the presence of vehicle alone (data not shown). 
Table 2 Percentage of dead cells in WEHI7.2 and hydrogen peroxide-resistant cell cultures in response to $1 \mu \mathrm{M}$ etoposide, $100 \mathrm{nM}$ staurosporine, $100 \mathrm{nM}$ thapsigargin or vehicle alone

\begin{tabular}{lccc}
\hline Cell variant & Etoposide & Staurosporine & Thapsigargin \\
\hline WEHI7.2 & $96.32 \pm 0.40 \dagger$ & $87.89 \pm 0.97$ & $94.63 \pm 0.29$ \\
50R & $98.29 \pm 0.25$ & $85.05 \pm 1.62$ & $97.34 \pm 0.41$ \\
100R & $97.11 \pm 0.73$ & $85.27 \pm 1.74$ & $96.90 \pm 0.32$ \\
200R & $95.64 \pm 0.21$ & $68.04 \pm 1.49^{*}$ & $17.22 \pm 0.58$ \\
\hline
\end{tabular}

$\dagger$ Values represent the mean \pm S.E.M. of triplicate samples in an experiment which has been replicated. ${ }^{*}$ Denotes a significant decrease in cell death compared to WEHI7.2 cells

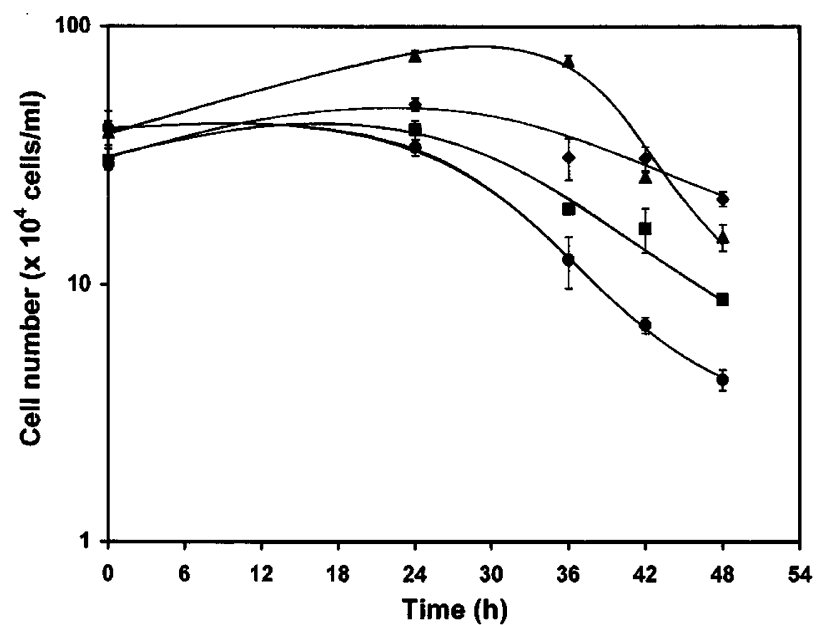

Figure 3 Comparison of dexamethasone-induced apoptosis in the WEHI7.2 parental and $\mathrm{H}_{2} \mathrm{O}_{2}$-resistant cell variants. Viable cell number over time in cultures after the addition of $1 \mu \mathrm{M}$ dexamethasone in parental $(\mathbf{O}), 50 \mathrm{R}(\boldsymbol{\square})$, $100 \mathrm{R}(\boldsymbol{\Delta})$, and $200 \mathrm{R}(\boldsymbol{)})$ cells is shown. Each symbol represents an average \pm S.E.M. of triplicate samples in a representative experiment, which has been replicated

\section{Bcl-2 status}

We examined the $\mathrm{Bcl}-2$ status of the $\mathrm{H}_{2} \mathrm{O}_{2} \mathrm{R}$ cell variants to determine whether alterations in $\mathrm{Bcl}-2$ could explain the dexamethasone resistance in the $\mathrm{H}_{2} \mathrm{O}_{2} \mathrm{R}$ cell variants. $\mathrm{Bcl}-2$ protects cells from apoptosis induced by a number of agents, including both dexamethasone and $\mathrm{H}_{2} \mathrm{O}_{2},{ }^{20,38,39}$ and may play a role in the cellular response to oxidative stress. ${ }^{20,40-42}$ No consistent alterations in $\mathrm{Bcl}-2$ protein or pattern of expression that could explain the resistance to dexamethasone was found (Figure 4).

\section{Delayed loss of cytochrome $\boldsymbol{c}$ into the cytosol}

Two major cellular apoptotic pathways have been elucidated, the death receptor pathway and the mitochondrial pathway. These are activated by different agents and use different activator caspases. ${ }^{43}$ Data from caspase knockout mice suggest that dexamethasone induces apoptosis in thymocytes via the mitochondrial pathway. ${ }^{4-46}$ In this pathway, an as yet unknown series of events (the signaling phase) results in the release of cytochrome $c$ from the mitochondria into the cytosol (the commitment to die). Released cytochrome $c$ triggers caspase activation resulting in cleavage of cellular targets (execution phase). To determine whether the 200R

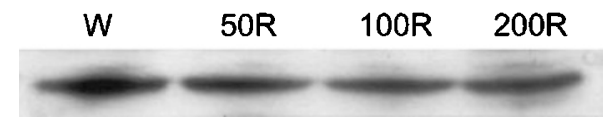

Figure 4 Comparison of cellular Bcl-2 protein content in parental WEHI7.2 and $\mathrm{H}_{2} \mathrm{O}_{2}$-resistant cell variants. The immunoblot of $60 \mu \mathrm{g}$ total cellular protein probed with an anti-Bcl-2 antibody is representative of five separate determinations. Lanes are labeled as in Figure 2

cells were protected during the signaling phase of apoptosis, we compared the kinetics of cytochrome $c$ release after dexamethasone treatment in the WEHI7.2 parental cells to that in the 200R cells. Twenty-four hours after the addition of dexamethasone, cytochrome $c$ was easily detectable in the cytosol of the WEHI7.2 cells (Figure 5). In the 200R cells, the cytochrome $c$ release was delayed so that only a trace was detectable in the cytosol $24 \mathrm{~h}$ post-dexamethasone treatment; however, after $32 \mathrm{~h}$ in drug cytosolic cytochrome $c$ was readily detectable. The content of cytochrome $c$ oxidase subunit I, a mitochondrial specific protein, in all of the cytosolic preparations was minimal and similar (data not shown). This indicates that the pattern of cytosolic cytochrome $c$ seen in Figure 5 was not due to contamination of the cytosolic preparation with mitochondria.

\section{Discussion}

Selection for resistance to $\mathrm{H}_{2} \mathrm{O}_{2}$ bolsters the endogenous antioxidant defense in WEHI7.2 cells and results in cell variants that are protected against dexamethasone-induced apoptosis. The delayed release of cytochrome $c$ into the cytosol in the 200R cells after dexamethasone treatment indicates that the protection occurs prior to the commitment to die. This suggests that ROS are involved in the signaling phase during steroid-mediated apoptosis. This ROS effect is separable from the hyperproduction of ROS identified in the later stages of apoptosis, induced by many agents, because the hyperproduction is thought to be caused by the disruption of the mitochondrial respiratory chain after release of cytochrome $c$ into the cytosol. ${ }^{14,24,25}$ Late stage ROS hyperproduction does not affect the apoptotic process per se, but may be an important epiphenomenon that affects the removal of apoptotic cells in tissues. ${ }^{47}$

The dexamethasone resistance of the $\mathrm{H}_{2} \mathrm{O}_{2} \mathrm{R}$ cell variants fits well with previous studies indicating that oxidative stress is a component of glucocorticoid-induced apoptosis. Exogenous addition of antioxidant enzymes, antioxidant vitamins or chemical antioxidants protects cells 


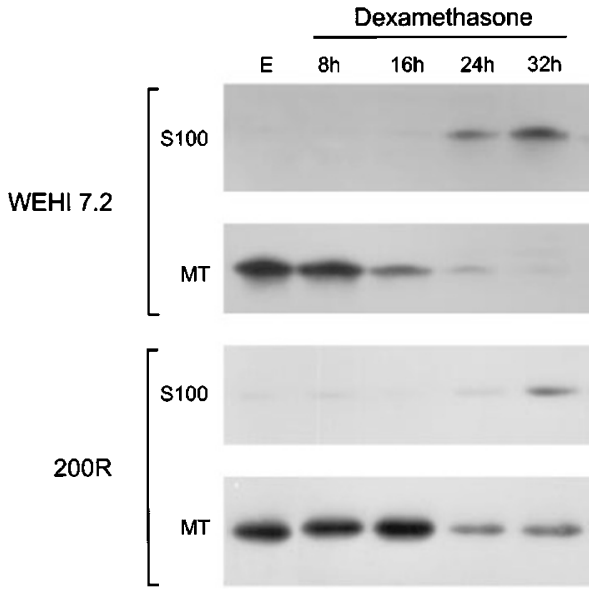

Figure 5 Comparison of the relative cytochrome $c$ content of cytosolic (S100) and mitochondrial (MT) fractions of WEHI7.2 and 200R cells over time after treatment with dexamethasone. A representative immunoblot shows control (C) and dexamethasone treated cell lysates probed with an anti-cytochrome $c$ antibody. The numbers indicate hours after the addition of $1 \mu \mathrm{M}$ dexamethasone. The immunoblot for the WEHI7.2 cells has been published previously in Cancer Research ${ }^{75}$

from steroid-induced apoptosis..$^{8,11-15,17}$ Hypoxia also protects WEHI7.2 cells from dexamethasone-induced apoptosis $^{8}$ and abrogates steroid-induced killing in immature thymocytes, ${ }^{15,18}$ although, one study found that either very low oxygen or hyperoxia enhances steroidinduced apoptosis in WEHI7.1 cells. ${ }^{48}$ Thymocytes are also protected by divalent ion chelators consistent with a role for the interaction of ROS and metals in Fenton-type chemistry during glucocorticoid-mediated apoptosis. ${ }^{11}$ A number of studies have shown that decreased concentrations of reduced glutathione accompany steroid-induced apoptosis, ${ }^{7,12-14,19}$ suggesting that cellular redox state is perturbed during this process. Increases in lipid peroxidation after glucocorticoid treatment, as a measurement of oxidative damage, are also seen in thymocytes ${ }^{19}$ and S49.1 lymphocytes. ${ }^{20}$

Our data demonstrates that the development of hydrogen peroxide resistance in the 200R cells delays cytochrome $c$ release supports a role for ROS in mediating a signaling event during steroid-induced lymphocyte apoptosis. One property of a signaling event is that it should occur relatively shortly after drug treatment. Studies aimed at establishing the chronology of apoptotic events support an early role for ROS. When apoptotic thymocyte populations are collected using Percoll gradients ${ }^{13}$ or identified by flow cytometry, ${ }^{16}$ small increases in ROS can be seen shortly after steroid treatment. The evidence of lipid peroxidation seen by Bustamante et al. ${ }^{19}$ also appeared shortly after drug treatment. Work by Kroemer and colleagues has shown that addition of catalase or $\mathrm{N}$-acetylcysteine, an antioxidant and glutathione precursor, to lymphocyte cultures delays the irreversible loss of mito-chondrial transmembrane potential and the hyperproduction of ROS. ${ }^{14,49}$ Signaling cascades in biological systems can be activated after transient exposure to small amounts of signal. Effective signaling concentra- tions of ROS may be below current detection limits. This could explain the decrease ${ }^{50}$ or a lack of change ${ }^{20}$ in ROS after steroid treatment reported in other studies with lymphoid cells.

Our results suggest multiple mechanisms of $\mathrm{H}_{2} \mathrm{O}_{2}$ resistance in the WEHI7.2 cells. Catalase, glutathione peroxidase and thioredoxin peroxidase are all enzymes potentially involved in the removal of cellular $\mathrm{H}_{2} \mathrm{O}_{2}$, therefore an increase in one or more of these enzymes might be expected in the $\mathrm{H}_{2} \mathrm{O}_{2} \mathrm{R}$ cells. The 50R and 200R cells both showed increased catalase activity, which correlated with the resistance to $\mathrm{H}_{2} \mathrm{O}_{2}$. In contrast, the $100 \mathrm{R}$ cells showed no increase in catalase activity yet exhibited $\mathrm{H}_{2} \mathrm{O}_{2}$ resistance. Lack of detectable glutathione peroxidase activity or increase in thioredoxin peroxidase mRNA expression suggest these enzymes do not account for the observed resistance.

Other groups have used similar strategies to produce a wide variety of $\mathrm{H}_{2} \mathrm{O}_{2}$-resistant cell lines. Although the common theme for these studies is $\mathrm{H}_{2} \mathrm{O}_{2}$ resistance, the observed changes in antioxidant enzymes vary widely. In $\mathrm{H}_{2} \mathrm{O}_{2}$-resistant $\mathrm{HA}-1$ Chinese hamster fibroblasts, increases in catalase activity and protein are correlated with $\mathrm{H}_{2} \mathrm{O}_{2}$ resistance. ${ }^{51}$ Similarly, the $\mathrm{H}_{2} \mathrm{O}_{2}$-resistant MCF-7 breast cancer cells, ${ }^{52} \mathrm{HL}-60$ leukemia cells ${ }^{53}$ and the $\mathrm{CHL}$ Chinese hamster fibroblasts ${ }^{54}$ show increased catalase. However, $\mathrm{H}_{2} \mathrm{O}_{2}$ resistance in $\mathrm{PC} 12$ rat pheochromocytoma cells is not due to an increase in either catalase or glutathione peroxidase. ${ }^{55}$ The Chinese hamster ovary cells developed by Cantoni et al. ${ }^{56}$ also do not show a correlation between catalase activity and $\mathrm{H}_{2} \mathrm{O}_{2}$ resistance. In this case, the cells resistant to the highest concentration of $\mathrm{H}_{2} \mathrm{O}_{2}$ (selected for growth in $850 \mu \mathrm{M} \mathrm{H} \mathrm{H}_{2} \mathrm{O}_{2}$ ) exhibit a lower catalase activity than cells that display an intermediate resistance to $\mathrm{H}_{2} \mathrm{O}_{2}$ (selected for growth in $250 \mu \mathrm{M}$ $\mathrm{H}_{2} \mathrm{O}_{2}$ ). Cells appear to adapt to the same challenge using cell-type specific mechanisms and can show multiple mechanisms of resistance, some of which appear to be concentration-dependent. Alterations in groups of antioxidant enzymes in response to a single type of challenge suggests that coordinate regulation occurs.

Coordinate changes in groups of enzymes during the adaptation to one type of oxidative stress often confer resistance to other agents. The cross-resistance phenomenon can provide clues to the mechanism by which another compound is lethal because it suggests that resistance to both agents requires something in common. The $\mathrm{H}_{2} \mathrm{O}_{2} \mathrm{R}$ cells here show increased resistance to oxidants, both $\mathrm{H}_{2} \mathrm{O}_{2}$ and paraquat, as well as dexamethasone. The $200 \mathrm{R}$ cells, with the greatest resistance to $\mathrm{H}_{2} \mathrm{O}_{2}$ and dexamethasone, are also resistant to staurosporine and thapsigargin, agents which have been reported to induce oxidative stress, ${ }^{19,57}$ even though this may not be the major pathway by which they induce apoptosis. That the $200 \mathrm{R}$ cells and WEHI7.2 cells are equally sensitive to etoposide, which does not stimulate an increase in ROS in thymocytes, ${ }^{19}$ suggests that not all apoptotic pathways are altered in these cells. Further support for a role for ROS in glucocorticoid-induced apoptosis comes from the observation that the steroid-resistant WEHI7.2 mutants 
isolated by Flomerfelt and Miesfeld ${ }^{58}$ are resistant to hydrogen peroxide. Overexpression of thioredoxin in WEHI7.2 cells also confers resistance to dexamethasone $^{34}$ while transfection of the same cell type with a redox-inactive thioredoxin mutant sensitizes the cells to dexamethasone. ${ }^{59}$ Comparison of the cell loss rate in each of the three cell variants described here suggests that increases in catalase activity are most closely correlated with increased protection.

In our model for dexamethasone-induced lymphocyte apoptosis, the downregulation of antioxidant defense enzymes by dexamethasone results in an increase in intracellular ROS because the cells can no longer remove the ROS generated by normal metabolism. The increase in ROS either by itself or due to oxidative damage initiates a signaling cascade that results in the release of cytochrome $c$ from the mitochondria. Binding of cytochrome $c$ to Apaf- 1 and procaspase- 9 in the apoptosome then initiates activation of the caspases. The simplest explanation for the steroid resistance seen in the $\mathrm{H}_{2} \mathrm{O}_{2} \mathrm{R}$ cells is that the increased antioxidant defense removes more of the ROS generated by dexamethasone treatment so that the ROS signal is not generated or the ROS damage does not occur. However, there are other potential models. A second possibility is that the ROS increase due to dexamethasone treatment occurs, but the redox status of the cells is altered so a redox-sensitive pathway remains unstimulated and the signal does not propagate. The resistance of the 200R cells to both staurosporine and thapsigargin suggests potential signaling pathways containing protein kinases or $\mathrm{Ca}^{2+}$ could be involved. Signaling pathways involving each of these components have been implicated in steroid-induced lymphocyte apoptosis. ${ }^{60-64} \mathrm{~A}$ third possibility is that an altered redox state in the $\mathrm{H}_{2} \mathrm{O}_{2} \mathrm{R}$ cells provides protection for the mitochondria so that, although the signaling cascade is activated, the mitochondria resist cytochrome $c$ release. The $\mathrm{H}_{2} \mathrm{O}_{2} \mathrm{R}$ cells will provide an excellent tool to test these possibilities.

\section{Materials and Methods}

\section{Cell culture}

The mouse thymoma-derived WEHI7.2 parental cell line ${ }^{65}$ was obtained from Dr. Roger Miesfeld (University of Arizona, Tucson, AZ, USA). Cells were maintained in Dulbecco's Modified Eagle Medium-low glucose (GIBCO-BRL Products, Grand Island, NY, USA) supplemented with $10 \%$ calf serum (Hyclone Laboratories, Logan, UT, USA) at $37^{\circ} \mathrm{C}$ in a $5 \% \mathrm{CO}_{2}$ humidified environment. Cells were maintained in exponential growth at a density between 0.02 and $2 \times 10^{6} \mathrm{cell} / \mathrm{s} / \mathrm{ml}$. Prior to each experiment, live cells were separated from the spontaneously apoptotic cells in the culture using FicollPlaque Plus reagents and the manufacturer's procedure for isolation of lymphocytes (Amersham Pharmacia Biotech, Piscataway, NJ, USA).

\section{Chemicals and drugs}

All chemicals and drugs used in these experiments were obtained from Sigma Chemical Co. (St. Louis, MO, USA) unless otherwise noted.

\section{Selection of hydrogen peroxide-resistant cells}

Cells were subcultured and treated with freshly diluted $\mathrm{H}_{2} \mathrm{O}_{2}$ resulting in a final concentration of $50 \mu \mathrm{M} \mathrm{H}_{2} \mathrm{O}_{2}$ in the culture medium. Growth was allowed to continue for 3 days, then the cells were counted, subcultured and treated with fresh $\mathrm{H}_{2} \mathrm{O}_{2}$. This routine continued until the doubling time of the cells reached a plateau (approximately 3 weeks). An aliquot containing $5 \times 10^{5}$ cells was then transferred to the next highest $\mathrm{H}_{2} \mathrm{O}_{2}$ concentration $(100 \mu \mathrm{M})$ and the same procedure followed. Cells were also maintained in $50 \mu \mathrm{M} \mathrm{H}_{2} \mathrm{O}_{2}$ by subculturing every 3 days in fresh $\mathrm{H}_{2} \mathrm{O}_{2}$-containing medium. After cells were adapted to $100 \mu \mathrm{M} \mathrm{H}_{2} \mathrm{O}_{2}$ (approximately 2.5 weeks), one aliquot was transferred to a new culture and treated with $200 \mu \mathrm{M} \mathrm{H}_{2} \mathrm{O}_{2}$ while another aliquot of cells was used to maintain the $100 \mu \mathrm{M}$-resistant population. Cells were adapted to culture in the presence of $200 \mu \mathrm{M}$ $\mathrm{H}_{2} \mathrm{O}_{2}$ (approximately 2 weeks) and maintained by continuous subculture in the presence of $200 \mu \mathrm{M} \mathrm{H}_{2} \mathrm{O}_{2}$. Initial transfer of the cell aliquot from the lower to next highest concentration of $\mathrm{H}_{2} \mathrm{O}_{2}$ did not kill more than $75 \%$ of the cells, thus, our strategy resulted in separate populations resistant to 50,100 or $200 \mu \mathrm{M} \mathrm{H}_{2} \mathrm{O}_{2}$. Prior to use in any experiments the cells were cultured in the absence of $\mathrm{H}_{2} \mathrm{O}_{2}$ for 5 or 6 days.

\section{Enzyme activity assays}

Prior to enzyme activity measurements, cells were washed twice with phosphate-buffered saline (PBS) at $4^{\circ} \mathrm{C}$. For the measurement of catalase, cells were resuspended in $10 \mathrm{mM}$ Tris- $\mathrm{HCl}, \mathrm{pH} 7.5,250 \mathrm{mM}$ sucrose, $1 \mathrm{mM}$ EDTA, $0.5 \mathrm{mM}$ dithiothreitol, $0.1 \mathrm{mM}$ phenylmethylsulfonyl fluoride and $1 \%$ Triton X-100. Samples were incubated for $30 \mathrm{~min}$ at $4^{\circ} \mathrm{C}$ and centrifuged at $10000 \times \mathrm{g}$ for $15 \mathrm{~min}$ at $4^{\circ} \mathrm{C}$. Activity was measured in the supernatant fractions as the decrease in $\mathrm{H}_{2} \mathrm{O}_{2}$ absorbance at $240 \mathrm{~nm}$ as described by Beers and Sizer ${ }^{66}$ and calculated using an extinction coefficient of $43.6 \mathrm{M}^{-1} \mathrm{~cm}^{-1}$. Total superoxide dismutase activity was measured using the method of Paoletti et al. ${ }^{67}$ Briefly, cells were sonicated (Vibra Cell, Sonics \& Materials, Inc., Danbury, CT, USA) in $100 \mathrm{mM}$ triethanolaminediethanolamine buffer, $\mathrm{pH}$ 7.4. Activity was measured by the inhibition of superoxide-dependent NADH oxidation using cell lysates and compared to that of purified enzyme. One unit of enzyme is defined as that which causes $50 \%$ inhibition. Glutathione S-transferase activity was measured using a 1-chloro-2,4 dinitrobenzene substrate as in Habig et al. ${ }^{68}$ Cells were lysed in PBS containing $0.1 \%$ Triton X-100 and centrifuged at $10000 \times g$ for $5 \mathrm{~min}$ at $4^{\circ} \mathrm{C}$ before the assay. Activity was calculated using an extinction coefficient of $9.6 \mathrm{mM}^{-1} \mathrm{~cm}^{-1}$. Selenium-dependent glutathione peroxidase was measured by preparing the samples as for catalase activity and assayed using $\mathrm{H}_{2} \mathrm{O}_{2}$ as a substrate as described in Zhang et al. ${ }^{30}$ Non-selenium dependent glutathione peroxidase activity was measured in the same samples using cumene hydroperoxide as a substrate. $^{30}$ Glutathione peroxidase activity was calculated by comparison to the activity of purified protein. All enzyme activities were normalized to cellular protein, measured using the BCA protein assay kit (Pierce, Rockford, IL, USA) according to manufacturer's instructions.

\section{Measurement of sensitivity to drugs}

Sensitivity to $\mathrm{H}_{2} \mathrm{O}_{2}$ or paraquat (methyl viologen) was determined by subculturing cells in the presence or absence of drug. After incubation for $48 \mathrm{~h}$, an aliquot of the culture was mixed with an equal volume of a $1 \mathrm{mg} \mathrm{ml}$ Eosin $Y$ solution and allowed to stand for a few minutes. Cells that excluded dye were scored as viable. For each particular cell 
variant and treatment, data are expressed as a ratio of the viable cell number in the presence of drug to the viable cell number in the absence of drug $\times 100$.

Sensitivity to dexamethasone-induced apoptosis was measured by treating cells with either a final concentration of $1 \mu \mathrm{M}$ dexamethasone in an ethanol vehicle (final ethanol concentration $=0.01 \%$ ) or an equivalent amount of vehicle alone and periodically scoring viable cells based on dye exclusion as described above. At selected timepoints, an aliquot of cell culture was removed for morphological assessment. Cells were washed twice in PBS and fixed in 3\% glutaraldehyde in $100 \mathrm{mM}$ cacodylate, $\mathrm{pH} \mathrm{7.2,} \mathrm{for} 1 \mathrm{~h}$. Subsequently,

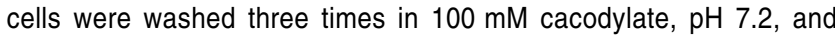
embedded in epoxy resin. One $\mu \mathrm{m}$-thick sections from these blocks were stained with toluidine blue for bright field microscopy.

Cell death due to etoposide, staurosporine and thapsigargin was measured by treating cells with $1 \mu \mathrm{M}$ etoposide for $16 \mathrm{~h}, 100 \mathrm{nM}$ staurosporine for $24 \mathrm{~h}, 100 \mathrm{nM}$ thapsigargin for $24 \mathrm{~h}$ or dimethyl sulfoxide (DMSO) vehicle alone (final concentration $=0.01 \%$ ) for similar periods. The relative percentage of dead cells in the cultures was determined using an apoptosis detection kit (R \& D Systems, Inc., Minneapolis, MN, USA) according to the manufacturer's protocol. Cellular fluorescence was measured and the data analyzed using a FACscan flow cytometer with CELLQuest software (Becton Dickenson, San Jose, CA, USA). The percentage of dead cells in the culture represents those cells that are annexin $\mathrm{V}$ positive.

\section{Glucocorticoid receptor number measurements}

Receptor number was compared by transient transfections of parallel cultures with a vector encoding green fluorescent protein (GFP) (EGFP.C1 Clontech Laboratories, Inc., Palo Alto, CA, USA) or a glucocorticoid response element/GFP reporter plasmid constructed from the same vector (donated by Dr. Roger Miesfeld) using a method similar to Askew et al. ${ }^{69}$ Briefly, cells were transfected by electroporation and allowed to recover for $16 \mathrm{~h}$. Cultures of cells transfected with the glucocorticoid responsive GFP were treated with $1 \mu \mathrm{M}$ dexamethasone for $24 \mathrm{~h}$ and assayed for fluorescence by flow cytometry using the LYSIS II analysis program (FACScan, Becton Dickinson, USA). Transfections with the non-glucocorticoid responsive GFP were used to correct for transfection efficiency.

\section{Northern blots}

Cells were harvested by centrifugation and the cell pellet frozen dry at $-80^{\circ} \mathrm{C}$ until use. RNA was isolated from the cell pellet using the RNaid kit (Bio 101, Inc., La Jolla, CA, USA) and the manufacturer's suggested protocol except that the cell pellet was sonicated into the lysis buffer at the beginning of the isolation. Fifteen $\mu \mathrm{g}$ RNA per sample was loaded onto a gel, electrophoresed and blotted onto Duralon membranes (Stratagene, La Jolla, CA, USA) according to standard protocols. ${ }^{70}$ RNA was attached to the membranes by UV cross-linking (Stratalinker, Stratagene, La Jolla, CA, USA). Glyceraldehyde 3-phosphate dehydrogenase (GAPDH) CDNA was obtained as previously described by Siemankowski et al. ${ }^{71} \mathrm{cDNAs}$ for the three human thioredoxin peroxidase isoforms, AOE372, ${ }^{32}$ NKEFA and NKEFB, ${ }^{33}$ were a kind gift from Margareta Berggren (Dr. Garth Powis' laboratory, University of Arizona, Tucson, AZ, USA). These sequences were obtained by using RT-PCR to clone them from Jurkat cell mRNA. The resulting cDNAs were inserted into the multiple cloning site of the pBK-CMV vector (Stratagene) and sequenced for confirmation. Target cDNA sequences were excised, purified and ${ }^{32} \mathrm{P}$-labeled probes made as previously described. ${ }^{71}$ Blots were probed using standard protocols. ${ }^{70}$ Transcript levels were quantitated by exposure of the membrane to a phosphorimager screen (Molecular Dynamics, Sunnyvale, CA, USA). GAPDH transcript levels were used to correct for differences in loading and transfer.

\section{Measurement of cytochrome $\mathrm{c}$ and $\mathrm{Bcl}-2$}

Cell cultures were treated with $1 \mu \mathrm{M}$ dexamethasone or vehicle as described above and harvested by centrifugation $(1000 \times g$ for $5 \mathrm{~min}$ at $4{ }^{\circ} \mathrm{C}$ ). Cell pellets were washed with PBS and the cytosolic (S100) and mitochondrial fractions prepared as in Vander Heiden et al. ${ }^{72}$ except that cells were resuspended in buffer $A$ without sucrose and allowed to sit for $30 \mathrm{~min}$ before the addition of sucrose to make a final concentration of $250 \mathrm{mM}$. Cells were immediately lysed by douncing, using 20 strokes in a $7 \mathrm{ml}$ glass homogenizer with a glass pestle (Kontes, Vineland, NJ, USA). Proteins from cytosolic and mitochondrial fractions ( $30 \mu \mathrm{g}$ of each sample) were separated on a $15 \%$ SDS-PAGE gel $^{73}$ and proteins transferred onto PVDF membranes (NEN Research Products, Boston, MA, USA) using a $25 \mathrm{~mA}$ current at $4{ }^{\circ} \mathrm{C}$ overnight in blotting buffer. ${ }^{74}$ Blots were probed for cytochrome $c$ using $1 \mu \mathrm{g} / \mathrm{ml}$ anti-cytochrome $c$ antibody (PharMingen, San Diego, CA, USA) and cytochrome $c$ oxidase using $1 \mu \mathrm{g} / \mathrm{ml}$ anti-cytochrome oxidase subunit I antibody (Molecular Probes, Eugene, OR, USA) using the manufacturer's protocol accompanying the cytochrome $c$ antibody. Proteins were detected by first incubating with a 1:2000 dilution of horseradish peroxidaselinked anti-mouse Ig (Amersham Pharmacia Biotech), then visualizing the product by incubation with chemiluminescence reagents (Renaissance Western Blot Chemiluminescence Reagent Plus, NEN Research Products) as suggested by the manufacturer and exposure to film (X-OMAT Blue, Kodak, Rochester, NY, USA).

For measurement of $\mathrm{Bcl}-2$, samples were prepared as for the catalase enzyme activity assay, then $60 \mu \mathrm{g}$ protein separated on a $15 \%$ SDS-PAGE gel and transferred to a PVDF membrane as described above. Bcl-2 was detected by incubation of the membrane with a 1:1000 dilution of anti-mouse $\mathrm{Bcl}-2$ antibody (Upstate Biotechnology, Lake Placid, NY, USA) using the protocol accompanying the $\mathrm{Bcl}-2$ antibody. After incubation with anti-Bcl-2, the membranes were incubated with horseradish peroxidase-linked anti-rabbit IgG antibody (Jackson ImmunoResearch Laboratories, Inc., West Grove, PA, USA) at a 1:80000 dilution, treated with chemiluminescence reagents (ECL Western Blotting Analysis System, Amersham Pharmacia Biotech) and exposed to film.

\section{Statistics}

Means were compared using ANOVA or a Student's $t$-test assuming unequal variances. Significant difference was set at $P<0.05$.

\section{Acknowledgements}

We thank Margareta Berggren (from Dr. Garth Powis' laboratory) for the thioredoxin peroxidase cDNAs; Dr. Dave Askew for advice on and the vectors for the receptor number determinations; and Dr. Amanda Baker for critical reading of the manuscript. This work was supported by a grant from the N.C.I. (CA 71768) to MM Briehl. ME Tome was partially supported by a T32 grant traineeship from the N.C.I. (CA 09213). 


\section{References}

1. Schwartzman RA and Cidlowski JA (1994) Glucocorticoid-induced apoptosis of lymphoid cells. Int. Arch. Allergy Immunol. 105: 347-354

2. Karin M (1998) New twists in gene regulation by glucocorticoid receptor: is DNA binding dispensable? Cell 93: 487-490

3. Liu ZG, Smith SW, McLaughlin KA, Schwartz LM and Osborne BA (1994) Apoptotic signals delivered through the T-cell receptor of a T-cell hybrid require the immediate-early gene nur77. Nature $367: 281-284$

4. Wang W, Wykrzykowska J, Johnson T, Sen R and Sen J (1999) ANF-kappa B/cmyc-dependent survival pathway is targeted by corticosteroids in immature thymocytes. J. Immunol. 162: 314-322

5. Geley S, Fiegl M, Hartmann BL and Kofler R (1996) Genes mediating glucocorticoid effects and mechanisms of their regulation. Rev. Physiol. Biochem. Pharmacol. 128: 1-97

6. Hartmann BL, Geley S, Loffler M, Hattmannstorfer R, Strasser-Wozak EM, Auer $B$ and Kofler R (1999) Bcl-2 interferes with the execution phase, but not upstream events, in glucocorticoid-induced leukemia apoptosis. Oncogene 18: 713-719

7. BriehI MM, Cotgreave IA and Powis G (1995) Downregulation of the antioxidant defence during glucocorticoid-mediated apoptosis. Cell Death Differ. 2: 41-46

8. Baker AF, BriehI MM, Dorr R and Powis G (1996) Decreased antioxidant defence and increased oxidant stress during dexamethasone-induced apoptosis: bcl-2 prevents the loss of antioxidant enzyme activity. Cell Death Differ. 3: 207-213

9. Ishikawa T, Esterbauer H and Sies H (1986) Role of cardiac glutathione transferase and of the glutathione S-conjugate export system in biotransformation of 4-hydroxynonenal in the heart. J. Biol. Chem. 261: 1576-1581

10. Cerutti PA (1985) Prooxidant states and tumor promotion. Science 227: $375-$ 381

11. Wolfe JT, Ross D and Cohen GM (1994) A role for metals and free radicals in the induction of apoptosis in thymocytes. FEBS Lett. 352: 58-62

12. Bustamante J, Slater AF and Orrenius S (1995) Antioxidant inhibition of thymocyte apoptosis by dihydrolipoic acid. Free Radic. Biol. Med. 19: 339-347

13. Slater AF, Nobel CS, Maellaro E, Bustamante J, Kimland M and Orrenius S (1995) Nitrone spin traps and a nitroxide antioxidant inhibit a common pathway of thymocyte apoptosis. Biochem J. 306: 771-778

14. Macho A, Hirsch T, Marzo I, Marchetti P, Dallaporta B, Susin SA, Zamzami Nand Kroemer G (1997) Glutathione depletion is an early and calcium elevation is a late event of thymocyte apoptosis. J. Immunol. 158: 4612-4619

15. McLaughlin KA, Osborne BA and Goldsby RA (1996) The role of oxygen in thymocyte apoptosis. Eur. J. Immunol. 26: 1170-1174

16. Torres-Roca JF, Lecoeur H, Amatore C and Gougeon M-L (1995) The early intracellular production of a reactive oxygen intermediate mediates apoptosis in dexamethasone-treated thymocytes. Cell Death Differ. 2: 309-319

17. Ramakrishnan N and Catravas GN (1992) N-(2-mercaptoethyl)-1,3-propanediamine (WR-1065) protects thymocytes from programmed cell death. J. Immunol. 148: 1817-1821

18. Stefanelli C, Stanic I, Bonavita F, Muscari C, Pignatti C, Rossoni C and Caldarera CM (1995) Oxygen tension influences DNA fragmentation and cell death in glucocorticoid-treated thymocytes. Biochem. Biophys. Res. Comm. 212: $300-$ 306

19. Bustamante J, Tovar-B A, Montero G and Boveris A (1997) Early redox changes during rat thymocyte apoptosis. Arch. Biochem. Biophys. 337: 121-128

20. Hockenbery DM, Oltvai ZN, Yin XM, Milliman CL and Korsmeyer SJ (1993) Bcl-2 functions in an antioxidant pathway to prevent apoptosis. Cell 75: 241-251

21. Slater AFG, Stefan C, Nobel I, van den Dobbelsteen DJ and Orrenius S (1996) Intracellular redox changes during apoptosis. Cell Death Differ. 3: 57-62

22. Hampton MB and Orrenius $S$ (1998) Redox regulation of apoptotic cell death in the immune system. Toxicol. Lett. 102: 355-358

23. Esposti MD and McLennan H (1998) Mitochondria and cells produce reactive oxygen species in virtual anaerobiosis: relevance to ceramide-induced apoptosis. FEBS Lett. 430: $338-342$

24. Kroemer G, Dallaporta B and Resche-Rigon M (1998) The mitochondrial death/ life regulator in apoptosis and necrosis. Annu. Rev. Physiol. 60: 619-642

25. Cai J and Jones DP (1998) Superoxide in apoptosis. Mitochondrial generation triggered by cytochrome c loss. J. Biol. Chem. 273: 11401-11404

26. Clement MV, Ponton A and Pervaiz S (1998) Apoptosis induced by hydrogen peroxide is mediated by decreased superoxide anion concentration and reduction of intracellular milieu. FEBS Lett. 440: 13-18
27. Wang X, Martindale JL, Liu Y and Holbrook NJ. (1998) The cellular response to oxidative stress: influences of mitogen-activated protein kinase signalling pathways on cell survival. Biochem. J. 333: 291-300

28. Krall J, Bagley AC, Mullenbach GT, Hallewell RA and Lynch RE (1988) Superoxide mediates the toxicity of paraquat for cultured mammalian cells. J. Biol. Chem. 263: 1910-1914

29. Fehsel K, Kroncke KD, Meyer KL, Huber H, Wahn V and Kolb-Bachofen V (1995) Nitric oxide induces apoptosis in mouse thymocytes. J. Immunol. 155: 2858 2865

30. Zhang LP, Maiorino M, Roveri A and Ursini F (1989) Phospholipid hydroperoxide glutathione peroxidase: specific activity in tissues of rats of different age and comparison with other glutathione peroxidases. Biochim. Biophys. Acta 1006: $140-143$

31. Chae HZ, Chung SJ and Rhee SG (1994) Thioredoxin-dependent peroxide reductase from yeast. J. Biol. Chem. 269: 27670-27678

32. Jin DY, Chae HZ, Rhee SG and Jeang KT (1997) Regulatory role for a novel human thioredoxin peroxidase in NF-kappaB activation. J. Biol. Chem. 272: $30952-30961$

33. Shau H, Butterfield LH, Chiu R and Kim A (1994) Cloning and sequence analysis of candidate human natural killer-enhancing factor genes. Immunogenetics 40 : $129-134$

34. Baker A, Payne CM, Briehl MM and Powis G (1997) Thioredoxin, a gene found overexpressed in human cancer, inhibits apoptosis in vitro and in vivo. Cancer Res. 57: 5162-5167

35. Walker PR, Smith C, Youdale T, Leblanc J, Whitfield JF and Sikorska M (1991) Topoisomerase II-reactive chemotherapeutic drugs induce apoptosis in thymocytes. Cancer Res. 51: 1078-1085

36. Lytton J, Westlin M and Hanley MR (1991) Thapsigargin inhibits the sarcoplasmic or endoplasmic reticulum Ca-ATPase family of calcium pumps. J. Biol. Chem. 266: 17067-17071

37. Harkin ST, Cohen GM and Gescher A (1998) Modulation of apoptosis in rat thymocytes by analogs of staurosporine: lack of direct association with inhibition of protein kinase C. Mol. Pharmacol. 54: 663-670

38. Miyashita Tand Reed JC (1992) bcl-2 gene transfer increases relative resistance of S49.1 and WEHI7.2 lymphoid cells to cell death and DNA fragmentation induced by glucocorticoids and multiple chemotherapeutic drugs. Cancer Res. 52: $5407-5411$

39. Pourzand C, Rossier G, Reelfs O, Borner C and Tyrrell RM (1997) Overexpression of Bcl-2 inhibits UVA-mediated immediate apoptosis in rat 6 fibroblasts: evidence for the involvement of $\mathrm{Bcl}-2$ as an antioxidant. Cancer Res. 57: $1405-1411$

40. Kane DJ, Sarafian TA, Anton R, Hahn H, Gralla EB, Valentine JS, Ord T and Bredesen DE (1993) Bcl-2 inhibition of neural death: decreased generation of reactive oxygen species. Science 262: 1274-1277

41. Gardner AM, Xu FH, Fady C, Jacoby FJ, Duffey DC, Tu Y and Lichtenstein A (1997) Apoptotic vs. nonapoptotic cytotoxicity induced by hydrogen peroxide. Free Radic. Biol. Med. 22: 73-83

42. Esposti MD, Hatzinisiriou I, McLennan H and Ralph S (1999) Bcl-2 and mitochondrial oxygen radicals. New approaches with reactive oxygen speciessensitive probes. J. Biol. Chem. 274: 29831-29837

43. Hengartner MO (2000) The biochemistry of apoptosis. Nature 407: 770-776

44. Yoshida H, Kong YY, Yoshida R, Elia AJ, Hakem A, Hakem R, Penninger JM and Mak TW (1998) Apaf1 is required for mitochondrial pathways of apoptosis and brain development. Cell 94: 739-750

45. Hakem R, Hakem A, Duncan GS, Henderson JT, Woo M, Soengas MS, Elia A, de la Pompa JL, Kagi D, Khoo W, Potter J, Yoshida R, Kaufman SA, Lowe SW, Penninger JM and Mak TW (1998) Differential requirement for caspase 9 in apoptotic pathways in vivo. Cell 94: $339-352$

46. Kuida K, Haydar TF, Kuan CY, GuY, Taya C, Karasuyama H, Su MS, Rakic P and Flavell RA (1998) Reduced apoptosis and cytochrome c-mediated caspase activation in mice lacking caspase 9. Cell 94: 325-337

47. Jiang S, Cai J, Wallace DC and Jones DP (1999) Cytochrome c-mediated apoptosis in cells lacking mitochondrial DNA. Signaling pathway involving release and caspase 3 activation is conserved. J. Biol. Chem. 274: 2990529911.

48. Muschel RJ, Bernhard EJ, Garza L, McKenna WG and Koch CJ (1995) Induction of apoptosis at different oxygen tensions: evidence that oxygen radicals do not mediate apoptotic signaling. Cancer Res. 55: 995-998 
49. Zamzami N, Marchetti P, Castedo M, Zanin C, Vayssiere JL, Petit PX and Kroemer G (1995) Reduction in mitochondrial potential constitutes an early irreversible step of programmed lymphocyte death in vivo. J. Exp. Med. 181: $1661-1672$

50. Wang JF, Jerrells TR and Spitzer JJ (1996) Decreased production of reactive oxygen intermediates is an early event during in vitro apoptosis of rat thymocytes. Free Radic. Biol. Med. 20: 533-542

51. Spitz DR, Li GC, McCormick ML, Sun Y and Oberley LW (1988) Stable H2O2resistant variants of Chinese hamster fibroblasts demonstrate increases in catalase activity. Radiat. Res. 114: 114-124

52. Akman SA, Forrest G, Chu FF and Doroshow JH (1989) Resistance to hydrogen peroxide associated with altered catalase mRNA stability in MCF7 breast cancer cells. Biochim. Biophys. Acta 1009: 70-74

53. Kasugai I and Yamada M (1989) Adaptation of human leukemia HL-60 cells to hydrogen peroxide as oxidative stress. Leuk. Res. 13: 757-762

54. Sawada M, Sofuni T and Ishidate Jr M (1988) Induction of chromosomal aberrations in active oxygen-generating systems. II. A study with hydrogen peroxide-resistant cells in culture. Mutat. Res. 197: 133-140

55. Jackson GR, Sampath D, Werrbach-Perez K and Perez-Polo JR (1994) Effects of nerve growth factor on catalase and glutathione peroxidase in a hydrogen peroxide-resistant pheochromocytoma subclone. Brain Res. 634: 69-76

56. Cantoni O, Guidarelli A, Sestili P, Mannello F, Gazzanelli G and Cattabeni F (1993) Development and characterization of hydrogen peroxide-resistant Chinese hamster ovary cell variants-I. Relationship between catalase activity and the induction/stability of the oxidant-resistant phenotype. Biochem. Pharmacol. 45: 2251-2257

57. Kruman I, Guo Q and Mattson MP (1998) Calcium and reactive oxygen species mediate staurosporine-induced mitochondrial dysfunction and apoptosis in PC12 cells. J. Neurosci. Res. 51: 293-308

58. Flomerfelt FA and Miesfeld RL (1994) Recessive mutations in a common pathway block thymocyte apoptosis induced by multiple signals. J. Cell Biol. 127: $1729-1742$

59. Freemerman AJ and Powis $G(2000)$ A redox-inactive thioredoxin reduces growth and enhances apoptosis in WEHI7.2 cells. Biochem. Biophys. Res. Commun. 274: 136-141

60. Cifone MG, Migliorati G, Parroni R, Marchetti C, Millimaggi D, Santoni A and Riccardi C (1999) Dexamethasone-induced thymocyte apoptosis: apoptotic signal involves the sequential activation of phosphoinositide-specific phospholipase C, acidic sphingomyelinase, and caspases. Blood 93: 22822296

61. Trubiani O, Borgatti P and Di Primio R (1994) Protein kinase C modulation in apoptotic rat thymocytes: an ultrastructural analysis. Histochemistry 102: $311-$ 316
62. Zucker RM, Elstein KH, Thomas DJ and Rogers JM (1994) Tributyltin and dexamethasone induce apoptosis in rat thymocytes by mutually antagonistic mechanisms. Toxicol. Appl. Pharmacol. 127: 163-170

63. Dowd DR, MacDonald PN, Komm BS, Haussler MR and Miesfeld R (1991) Evidence for early induction of calmodulin gene expression in lymphocytes undergoing glucocorticoid-mediated apoptosis. J. Biol. Chem. 266: 1842318426

64. Dowd DR, MacDonald PN, Komm BS, Haussler MR and Miesfled RL (1992) Stable expression of the calbindin-D28K complementary DNA interferes with the apoptotic pathway in lymphocytes. Mol. Endocrinol. 6: 1843-1848

65. Harris AW, Bankhurst AD, Mason S and Warner NL (1973) Differentiated functions expressed by cultured mouse lymphoma cells. II. Theta antigen, surface immunoglobulin and a receptor for antibody on cells of a thymoma cell line. J. Immunol. 110: 431-438

66. Beers RF and Sizer IW (1952) A spectrophotometric method for measuring the breakdown of hydrogen peroxide by catalase. J. Biol. Chem. 195: 133-140

67. Paoletti F, Aldinucci D, Mocali A and Caparrini A (1986) A sensitive spectrophotometric method for the determination of superoxide dismutase activity in tissue extracts. Anal. Biochemistry 154: 536-541

68. Habig WH, Pabst MJ and Jakoby WB (1974) Glutathione S-transferases. The first enzymatic step in mercapturic acid formation. J. Biol. Chem. 249: $7130-$ 7139

69. Askew DJ, Kuscuoglu U, Brunner T, Green DR and Miesfeld RL (1999) Characterization of apt-cell lines exhibiting cross-resistance to glucocorticoidand Fas-mediated apoptosis. Cell Death Differ. 6: 796-804

70. Sambrook J, Fritsch EF and Maniatis T (1989) Molecular Cloning: A Laboratory Manual. Cold Spring Harbor, NY: Cold Spring Harbor Press

71. Siemankowski LM, Morreale J and BriehI MM (1999) Antioxidant defenses in the TNF-treated MCF-7 cells: selective increase in MnSOD. Free Radic. Biol. Med. 26: $919-924$

72. Vander Heiden MG, Chandel NS, Williamson EK, Schumacker PT and Thompson CB (1997) Bcl-xL regulates the membrane potential and volume homeostasis of mitochondria. Cell 91: 627-637

73. Laemmli UK (1970) Cleavage of structural proteins during the assembly of the head of bacteriophage T4. Nature 227: $680-685$

74. Towbin H, Staehelin T and Gordon J (1979) Electrophoretic transfer of proteins from polyacrylamide gels to nitrocellulose sheets: procedure and some applications. Proc. Natl. Acad. Sci. USA 76: 4350-4354

75. Tome ME, Baker AF, Powis G, Payne CM and Briehl MM (2001) Catalaseoverexpressing thymocytes are resistant to glucocorticoid-induced apoptosis and exhibit increased net tumor growth. Cancer Res. 61: 2766-2773 